\title{
Interactive comment on "Bispectra of climate cycles show how ice ages are fuelled" by Diederik Liebrand and Anouk T. M. de Bakker
}

\author{
Diederik Liebrand and Anouk T. M. de Bakker \\ diederik@palaeoclimate.science \\ Received and published: 11 August 2019 \\ Please find the rubuttal to M. Crucifix's comments in the link below. \\ Please also note the supplement to this comment: \\ https://www.clim-past-discuss.net/cp-2019-43/cp-2019-43-AC1-supplement.pdf
}

Interactive comment on Clim. Past Discuss., https://doi.org/10.5194/cp-2019-43, 2019. 